\title{
Properties of Composition Geometric Modelling
}

\author{
Kseniia Lysenko, graduate student \\ Viktor Vereshchaga, Doctor of Science, Professor
}

\author{
Bogdan Khmelnitsky Melitopol State Pedagogical University, \\ Melitopol, Ukraine
}

\begin{abstract}
It is indicated that in order to use the original geometric figure in compositional geometric modelling, it is necessary to unify it, that is, to divide it into geometric and parametric components. Examples of unification by drawing up geometric BN-matrices and examples of creating compositional geometric models are given.

Keywords. Compositional geometric modelling, B-figures, unified geometric figure, geometric figure image (GF-image), Baliuby-Naidysh calculus (BN-calculus).
\end{abstract}

Formulation of the problem. The use of compositional geometric modelling $[4,8]$ requires a certain preparation of the initial geometric information, by moving to a unified geometric figure. The process of unification of the original geometric figure is simple, but requires certain methodological explanations. On the examples of one-parameter geometric figures, a technique for unifying a geometric figure using BN-matrices is provided [3].

Analysis of recent research. Recently, point BN-calculus has been developing [3, 5, 6, $7,8,9]$, on the basis of which compositional geometric modelling was created [1], the greatest development of which is shown in the dissertation work of Adonyev Ye. [2]. However, in this work, the main capabilities of the compositional method of geometric modelling were developed, without much detail.

The works [1,2] indicate general provisions for the creation of B-figures [8] using $\mathrm{BN}$-matrices [3]. However, these works do not talk about the unification of the original geometric figure.

This article explains in detail the process of unifying the original geometric figure with its subsequent application to create B-figures in compositional geometric modelling.

Formulation of the goals of the article (problem definition). The purpose of this article is to detail the process of unification of the initial geometric figure and the construction of B-figures in $n$-dimensional $E^{n}$ space in compositional geometric modelling.

Main part. The initial information for compositional geometric modelling is always a geometric figure, represented by an ordered set of points determined by the coordinates of the $n$-dimensional space $E^{n}$ in the global $n$-dimensional coordinate system.

To use a geometric figure in compositional geometric modelling, it is necessary to unify it, that is, turn it into a unified geometric figure, which has two components:

- parametric, which is a configuration and establishes a one-to-one relationship between the points of the original geometric figure; the parametric component is and is written in the form of a geometric $\mathrm{BN}$-matrix parametric; the parametric component reproduces in parametric form the relative position of the points of the original geometric figure;

- geometric, which is the current shape of the geometric figure and defines a changing ordered set of points of the original geometric figure every second. This set is written in the 
form of a point geometric BN-matrix. The geometric component recreates the number and layout of points on the original geometric shape, that is, on the corresponding segment.

The specified process of dividing the initial geometric figure into two components parametric and geometric, which are suitable for use in compositional geometric modelling, will be called the unification of the original geometric figure, and the result obtained will be called a unified geometric figure.

A unified geometric figure is a prototype, which is based on: computer modelling (shaping) of the design of a geometric figure, in which a purposeful gradual change in the geometric component of a unified geometric figure will generate the desired GF-image.

Thus, obtaining the GF-image will be called computer-oriented compositional geometric modelling.

Let us give a scheme of computer-oriented compositional geometric modelling.

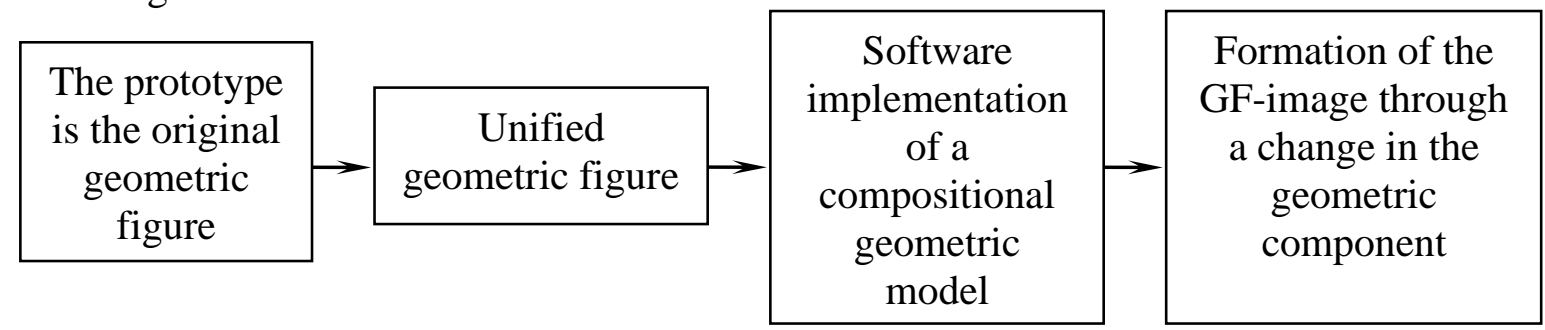

In the above diagram, one must understand:

- "Compositional geometric model" - BN-matrix parametric unified geometric figure;

- the shaping of the GF-image occurs due to computer experiments by purposefully changing the geometric component of a unified geometric figure and analyzing the results obtained in order to achieve the desired shape.

Here are some examples of unification.

1. Let the original geometric figure consist of three points, which represent a discrete curve. Let each of these three points be defined by ten coordinates. This triplet of points in the horizontal $U$ direction defines a discretely fed curve.

Based on the conditions of the problem, the point BN-matrix will look like:

$$
\left(\left(\begin{array}{lll}
A_{11} & A_{12} & A_{13}
\end{array}\right)\right) \text {. }
$$

Point BN-matrix (1) will correspond to ten coordinate BN-matrices-rows, according to the number of coordinates defining each of the initial points, $A_{1 j}$ for $j=\overline{1,3}$.

Let us present (2) the corresponding BN-matrices-rows coordinate:

$$
\begin{aligned}
& \left(\left(A_{11}(1) \quad A_{12}(1) \quad A_{13}(1)\right)\right) ;\left(\left(A_{11}(2) \quad A_{12}(2) \quad A_{13}(2)\right)\right) \text {, } \\
& \left(\left(A_{11}(9) \quad A_{12}(9) \quad A_{13}(9)\right)\right) ;\left(\left(A_{11}(10) \quad A_{12}(10) \quad A_{13}(10)\right)\right) \text {. }
\end{aligned}
$$

For the given example, the parametric BN-matrix will also have the form of a $\mathrm{BN}$ matrix-row:

$$
\left(\left(\begin{array}{lll}
P_{11} & P_{12} & P_{13}
\end{array}\right)\right), \text { where } \sum_{j=1}^{3} P_{1 j}=1,
$$

which will be the same for all coordinate $\mathrm{BN}$-matrices-rows from (2). 
Interpolation curve matrix $\left(M_{\Phi}\right)$ for a discretely submitted curve in the BN-matrix form should be defined as the product of $\mathrm{BN}$-matrices-rows (1) point and (3) parametric:

$$
M_{\Phi}=\left(\left(A_{1 j}\right)\right) \cdot\left(\left(P_{1 j}\right)\right), \text { for } j=\overline{1,3}
$$

or in expanded form:

$$
M_{\Phi}=\left(\left(\begin{array}{lll}
A_{11} & A_{12} & A_{13}
\end{array}\right)\right) \cdot\left(\left(\begin{array}{lll}
P_{11} & P_{12} & P_{13}
\end{array}\right)\right)=\left(\left(\begin{array}{lll}
A_{11} P_{11} & A_{12} P_{12} & A_{13} P_{13}
\end{array}\right)\right) .
$$

Interpolation curve $M$ for a discretely given curve in point form is defined as the sum of the elements of the BN-matrix (4):

$$
M=\sum_{j=1}^{3} A_{1 j} P_{1 j}
$$

Taking into account (2) and (4), we can compose coordinate equations for each of the ten axes:

$$
M(1)=\sum_{j=1}^{3} A_{1 j}(1) \cdot P_{1 j} ; M(2)=\sum_{j=1}^{3} A_{1 j}(2) \cdot P_{1 j} ; \ldots ; M(9)=\sum_{j=1}^{3} A_{1 j}(9) \cdot P_{1 j} ;
$$

$M(10)=\sum_{j=1}^{3} A_{1 j}(10) \cdot P_{1 j}$, where $A_{1 j}(n)$ - coordinate values of three points along the $n^{\text {th }}$ axis.

2. Let the original geometric figure consist of three points, which represent a discretely filed curve in 10-dimensional $E^{10}$ space in the transverse direction $V$ with respect to $U$ (example 1).

In this case, the starting points $A_{1 j}$, for $j=\overline{1,3}$ will be located in a column and the corresponding to this geometric figure $\mathrm{BN}$-matrix-point and parametric will be $\mathrm{BN}$-matrixcolumns.

$$
\left(\left(\begin{array}{l}
A_{11} \\
A_{21} \\
A_{31}
\end{array}\right)\right) .
$$

- BN-matrices are point towards $V$.

$$
\left(\left(\begin{array}{l}
P_{11} \\
P_{21} \\
P_{31}
\end{array}\right)\right) .
$$

- BN-matrices are parametric (for which $\sum_{i=1}^{3} P_{i 1}=1$ ) towards $V$.

For a point BN-matrix from (7), it is necessary to compose ten BN-matrices coordinate, which will correspond to ten coordinate axes, which will also be in the form of columns: 


$$
\left(\left(\begin{array}{l}
A_{11}(1) \\
A_{21}(1) \\
A_{31}(1)
\end{array}\right)\right)\left(\left(\begin{array}{l}
A_{11}(2) \\
A_{21}(2) \\
A_{31}(2)
\end{array}\right)\right) \cdots\left(\left(\begin{array}{l}
A_{11}(9) \\
A_{21}(9) \\
A_{31}(9)
\end{array}\right)\right)\left(\left(\begin{array}{l}
A_{11}(10) \\
A_{21}(10) \\
A_{31}(10)
\end{array}\right)\right) .
$$

The parametric $\mathrm{BN}$-matrix from (7) for all coordinate $\mathrm{BN}$-matrices (8) will be the same.

Thus, the geometric $\mathrm{BN}$-matrix $M_{\Phi}$ of the original geometric figure is defined as the product of two matrices from (7) and has the form:

$$
M_{\Phi}=\left(\left(\begin{array}{l}
A_{11} P_{11} \\
A_{21} P_{21} \\
A_{31} P_{31}
\end{array}\right)\right) .
$$

Interpolation curve $M$ for a discretely given curve in a point form for the direction $V$, is defined as the sum of the elements of the BN-matrix (9), [2] and has the form:

$$
M=\sum_{i=1}^{3} A_{i 1} P_{i 1} .
$$

Then the projections of the interpolation curve (10) onto each of the ten axes $E^{n}$ of the space will have the form:

$$
M(1)=\sum_{i=1}^{3} A_{i 1}(1) \cdot P_{i 1}-\text { for } 1 \text { st axis; } M(2)=\sum_{i=1}^{3} A_{i 1}(2) \cdot P_{i 1}-\text { for } 2 \text { st axis; } \ldots ;
$$

$M(9)=\sum_{i=1}^{3} A_{i 1}(9) \cdot P_{i 1}-$ for 9st axis; $M(10)=\sum_{i=1}^{3} A_{i 1}(10) \cdot P_{i 1}-$ for 10st axis, where $A_{1 j}(n)$ - coordinate values on the $n^{\text {th }}$ axis.

Conclusions. One of the main features of compositional geometric modelling is the need to create a unified geometric figure, which is a powerful toolkit for the formation of compositional models, contributes to a faster and more efficient shaping of the required geometric figure - decoupling.

As it was shown, the creation of geometric BN-matrices occurs in such a way that their elements are located in full accordance with the location of points on the original geometric figure. The lack of such a match leads to an erroneous solution to the problem.

The use of BN-matrices provides the possibility of fast and error-free obtaining of compositional geometric models and is an effective abbreviated record of point and calculated coordinate forms.

\section{References}

1. Vereshchaha V.M. Kompozytsiine heometrychne modeliuvannia: monohrafiia / V.M. Vereshchaha - Melitopol: FOP Odnoroh T.V., 2017.-108 s.

2. Adoniev Ye.O. Kompozytsiinyi metod heometrychnoho modeliuvannia bahatofaktornykh system: dys..dokt.tekhn.nauk. - K.: KNUBA, 2018. - 512 s. 
3. Adoniev Ye.O., Vereshchaha V.M., Naidysh A.V. Zastosuvannia heometrychnykh matryts dlia utvorennia tochkovykh rivnian B-poverkhon / Ye.O. Adoniev, V.M. Vereshchaha, A.V. Naidysh // Naukovyi visnyk Tavriiskoho derzhavnoho ahrotekhnolohichnoho universytetu. - Melitopol: TDATU, 2018. - Vyp. 8, T.1, s. 153-160.

4. Adoniev Ye.O., Vereshchaha V.M. Kontseptualni zasady vykorystannia kompozytsiinoho metodu heometrychnoho modeliuvannia pry formuvanni optymalnoho portfeliu proektiv $\mathrm{z}$ enerhozberezhennia $\mathrm{v}$ navchalnykh zakladakh. I Suchasni problemy modeliuvannia: zb. nauk. prats - Melitopol: Vydavnytstvo MDPU im. B. Khmelnytskoho, 2017. - Vyp. 9. - S. 3-10.

5. Lysenko K.Iu., Naidysh A.V., Vereshchaha V.M., Adoniev Ye.O. Osnovy kompozytsiinoho heometrychnoho modeliuvannia: navchalnyi posibnyk. MDPU im. B. Khmelnytskoho. - Melitopol, 2019. — 255 s.

6. Lysenko K.Iu., Vereshchaha V.M., Baliuba I.H., Naidysh A.V. Parametryzatsiia bahatovymirnykh heometrychnykh obiektiv metodamy tochkovoho chyslennia Baliuby-Naidysha / Suchasni problemy modeliuvannia: zbirnyk naukovykh prats / MDPU im. B. Khmelnytskoho. - Melitopol, 2019. - Vyp.15. - S. 51-57.

7. Lysenko K.Iu., Naidysh A.V., Vereshchaha V.M., Baliuba I.H. Kompozytsiina interpoliatsiia ploskoi dyskretno podanoi kryvoi / Suchasni problemy modeliuvannia: zbirnyk naukovykh prats / MDPU im. B. Khmelnytskoho. - Melitopol, 2019. - Vyp.14. - S. 113-121.

8. Vereshchaha V.M. Kompozytsiinyi metod utvorennia B-poverkhon / V.M. Vereshchaha, Ye.O. Adoniev // Naukovyi zhurnal «Kompiuterno-intehrovani tekhnolohii: osvita, nauka, vyrobnytstvo». - Lutsk.: Lutskyi natsionalnyi tekhnichnyi universytet - 2017, №26, S. 36-41.

9. Lysenko K.Iu., Vereshchaha V.M., Naidysh A.V. Baliuby-Naidysha interpoliatsiia chotyrokh tochok u ploshchyni / Suchasni problemy modeliuvannia: naukove fakhove vydannia / MDPU im. B. Khmelnytskoho. - Melitopol, 2019. - V.13. - S. 100-105. 